\title{
Preparation, Physical Characterization and Antibacterial Activity of Ni (II), Cu (II), Co (II), Cd (II), Zn (II) and Cr (III) Schiff Base Complex Compounds
}

\author{
Md. Motahar Hossain 1, *, Md. Abul Bashar², Md. Nuruzzaman Khan³ ${ }^{3}$ Pijush Kanti Roy ${ }^{4}$, \\ Md. Siddik Ali ${ }^{1}$, Md. Akhter Farooque ${ }^{1}$ \\ ${ }^{1}$ Department of Chemistry, University of Rajshahi, Rajshahi, Bangladesh \\ ${ }^{2}$ Department of Textile Engineering, Khwaja Yunus Ali University, Sirajganj, Bangladesh \\ ${ }^{3}$ Department of Chemistry, Begum Rokeya University, Rangpur, Rangpur, Bangladesh \\ ${ }^{4}$ Department of Chemistry, Mawlana Bhashani Science and Technology University, Santosh, Tangail, Bangladesh
}

Email address:

motahar_chem aru.ac.bd (Md. M. Hossain), motaharbd7@gmail.com (Md. M. Hossain)

${ }^{*}$ Corresponding author

\section{To cite this article:}

Md. Motahar Hossain, Md. Abul Bashar, Md. Nuruzzaman Khan, Pijush Kanti Roy, Md. Siddik Ali, Md. Akhter Farooque. Preparation, Physical Characterization and Antibacterial Activity of Ni (II), Cu (II), Co (II), Cd (II), Zn (II) and Cr (III) Schiff Base Complex Compounds. Science Journal of Chemistry. Vol. 6, No. 2, 2018, pp. 17-23. doi: 10.11648/j.sjc.20180602.11

Received: June 13, 2018; Accepted: June 27, 2018; Published: July 23, 2018

\begin{abstract}
A Schiff base (SB) derived from p-hydroxy benzaldehyde and 4-aminobenzoic acid. The transition metal complexes of Ni (II), Cu (II), Co (II), Cd (II), Zn (II) and Cr (III) were prepared separately with the Schiff base (SB), which were used as ligand. Several physical tools, in particular; elemental analysis, molar conductivity, magnetic susceptibility, infrared spectroscopy (IR), electronic absorption spectroscopy (ESR) to investigate the chemical structure of the prepared transition metal complexes. The elemental analysis data show the formation of $1: 2\left[\mathrm{M}^{1}: 2 \mathrm{~L}\right]$ and $1: 3\left[\mathrm{M}^{2}: 3 \mathrm{~L}\right]$ complexes of the formula of $\mathrm{M}^{2+} \mathrm{L}_{2}$ and $\mathrm{M}^{3+} \mathrm{L}_{3}$, respectively where $\mathrm{M}^{2+}=\mathrm{Ni}$ (II), Cu (II), Co (II), Cd (II), Zn (II) and $\mathrm{M}^{3+}=\mathrm{Cr}$ (III) and $\mathrm{L}=\mathrm{Schiff}$ base (SB). The molar conductance (conductivity) measurements were revealed that all the complexes are nonelectrolyte in nature. The infrared (IR) spectral studies indicated the binding sites of the Schiff base ligand with the transition metal ions. The magnetic susceptibility measurements and electronic spectral results supported the predicted coordination geometry of the complexes and magnetic properties (para or dia-magnetic nature) of the complex compounds. The free Schiff base and its complexes have been tested for their antimicrobial activities against several human pathogenic (two gram-positive and two gram-negative) bacteria. The obtained results showed that the complex compounds exhibit moderate to strong antimicrobial activity compared with kanamycin and ampicillin.
\end{abstract}

Keywords: Schiff Base, Metal Complex, Spectral Studies, Antimicrobial Activity

\section{Introduction}

Schiff bases were first discovered by a German chemist, Nobel Prize winner, Hugo Schiff. Schiff base is a condensation product of any primary amine with an active carbonyl group of an aldehyde or a ketone under optimum conditions and contain the azomethine group $(-\mathrm{CH}=\mathrm{N}-$ or $>\mathrm{C}=\mathrm{N}-$ :). The structure of Schiff base implies that it (also known as imine or azomethine) is a nitrogen analogue of an aldehyde or ketone in which the carbonyl group (CO) has been substituted through an imine or azomethine group [1, 2, 3]. The Chemistry of Schiff-base complexes has attracted a great deal of attention ever since Pfeiffer carried out his pioneering research in the 1930's. In organic chemistry Schiff bases are most extensively utilized in pigments and dyes industries, catalysts, intermediate in organic synthesis, and as a polymer stabilizer [4-6]. Furthermore, Schiff bases and their metal complexes are also well known to have pronounced biological activity [12-13] and form an important class of compounds in medicine and pharmaceutical field. It 
also exhibited some degree of antibacterial, antifungal, antitumor, anticancer and anti-inflammatory activity [14-22], the azomethine linkage are responsible for the biological activity of Schiff bases. Transition metal complexes of these ligands exhibit varying configurations, structural liability and sensitivity to molecular environments. The central metal ions in these complexes act as active sites for pharmacological agent. This feature is employed for modelling active sites in biological systems [23-26]. Mixed -ligand complexes of $\mathrm{Cu}$ (II) containing the Schiff base ligand derived from 2hydroxybenxaldehyde with 2 -amino phenol/3-amino phenol and bidentate auxiliary ligands were synthesized and characterized by Kudrat et. al [3]. The authors observed that the complexes with Schiff bases exhibited the significant anti-microbial activity. Para-hydroxy benzaldehyde and 4aminobenzoic acid compounds are capable to form complexes with transition metal ions in the form of Schiff bases. The Schiff bases are important class of ligands in coordination chemistry and play an important role as extensive applications in different fields [6-8]. A large number of the metal complexes with different electronic structures have been synthesized using Schiff base ligands [9-12]. In recent years, metal complexes of Schiff bases have attracted considerable attention due to their remarkable antibacterial, antifungal and antitumor activities [13-17]. Previously, we had synthesized few transition metals complexes of such type and studied their antimicrobial activity [18]. It was observed that the complexes have potential antimicrobial activity. Keeping these facts in view the significance of metal in biology, we here in report the synthesis of the Schiff base by the condensation of p-hydroxy benzaldehyde and 4-aminobenzoic acid and complexation this Schiff base with several transition metals Ni (II), Cu (II), Co (II), Cd (II), Zn (II) and Cr (III) ions. Also, we characterized of the complexes on the basis of elemental analysis, conductivity and magnetic measurements and infrared spectral and electronic spectroscopy to investigate the structure of the complexes. In addition, the antimicrobial activities of these complexes were also reported here.
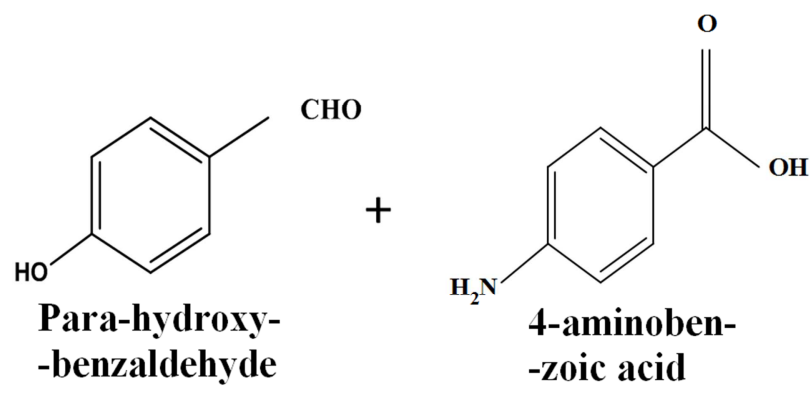

Figure 1. Reaction scheme for the preparation of Schiff base (SB).

The general mechanism of imine formation (scheme 2) begins as a nucleophilic addition to the carbonyl group. In this case, the nucleophile is the amine, which reacts with the aldehyde or ketone to give an instable addition product called

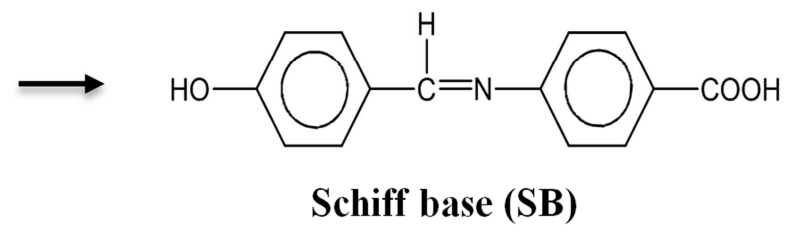

\section{Experimental}

\subsection{Materials}

All the chemicals used in this work were reagent chemically pure and reagents grade (BDH/Aldrich). Solvents were purified and dried according to standard procedures. Melting points of all metal complexes were measured by an electro thermal melting point apparatus model no. AZ6512. Elemental analysis for carbon, hydrogen and nitrogen were performed by Perkin 2400 Organic Elemental Analyzer II at Kayama University, Japan. The SHERWOOD SCIENTIFIC Magnetic Susceptibility Balance was used for measuring magnetic susceptibility of the metal complexes. Infrared spectra as $\mathrm{KBr}$ disc were recorded with a NICOLET 310 , FTIR Spectrophotometer, Belgium, from $4000-400 \mathrm{~cm}^{-1}$ in the Department of Metallurgy and Material Science, Bangladesh University of Engineering \& Technology (BUET), Dhaka, Bangladesh. UV-visible spectra were recorded with a SHIMADZU DOUBLE BEAM spectrophotometer (model UV-1200) from 200-900 nm in Central Science Laboratory, University of Rajshahi, Rajshahi-6205, Bangladesh.

\subsection{Preparation of Schiff Base}

The Schiff base was prepared by mixing stoichiometric ratio of p-hydroxy benzaldehyde in ethanol with ethanolic solution of 4-aminobenzoic acid. p-hydroxybenzaldehyde (1.37 $\mathrm{g}, 10 \mathrm{mmol})$ in absolute ethanol $(20 \mathrm{~mL})$ was added to an ethanolic $(30 \mathrm{~mL})$ solution of 4-aminobenzoic acid $(1.22 \mathrm{~g}$, $10 \mathrm{mmol})$. The mixture was stirred for 4 hours at ambient temperature. Then it was allowed to stand for 5 days at room temperature. The resulting solution was evaporated under vacuum to remove the solvent. The Product was collected by filtration, washed several times with ethanol and recrystallized from hot ethanol. The melting point of the product found to be $232^{\circ} \mathrm{C}$, and its purity was confirmed by TLC technique [27]. A yellow precipitate was observed and then dried under vacuum desiccator over anhydrous $\mathrm{CaCl}_{2}$. The reaction scheme of the preparation of Schiff base are given below (Figure 1):

a carbinolamine. A carbinolamine is a compound with an amine group $\left(-\mathrm{NH}_{2}\right)-\mathrm{NHR}$ or $-\mathrm{NR}$ ) and a hydroxyl group to the same carbon as in Figure 2. 
<smiles></smiles><smiles>[R]N=C(C)[C@H](C)C(C)C</smiles>

Figure 2. Reaction mechanism for the formation of azomethine group $(-\mathrm{CH}=\mathrm{N}-$ or $>\mathrm{C}=\mathrm{N}-)$ in Schiff base.

\subsection{Preparation of Schiff Base Complexes}

$1 \mathrm{mmol}$ of salt $\mathrm{Ni}\left(\mathrm{NO}_{3}\right)_{2} \cdot 6 \mathrm{H}_{2} \mathrm{O}, \mathrm{Cu} \quad\left(\mathrm{NO}_{3}\right)_{2} \cdot 3 \mathrm{H}_{2} \mathrm{O}$, $\mathrm{CoCl}_{2} \cdot 6 \mathrm{H}_{2} \mathrm{O}, \mathrm{Cd}\left(\mathrm{NO}_{3}\right)_{2} \cdot 4 \mathrm{H}_{2} \mathrm{O}, \mathrm{Zn}\left(\mathrm{NO}_{3}\right)_{2} \cdot 6 \mathrm{H} 2 \mathrm{O}$ and $\mathrm{Cr}$ $\left(\mathrm{NO}_{3}\right)_{3} .9 \mathrm{H}_{2} \mathrm{O}$ were individually dissolved in $10 \mathrm{ml}$ of absolute ethanol. The Schiff base (SB) solution was added to these salts solution separately and stirred for 4 hours at ambient temperature and allowed to stand for half an hour. The precipitate was formed as Schiff base complex compounds and were filtered off and dried in vacuo over anhydrous $\mathrm{CaCl}_{2}$. The general scheme of the complexes are mentioned as equation as;

$$
\mathrm{M}^{2+}+\mathrm{SB} \rightarrow\left[\mathrm{M}(\mathrm{SB})_{2}\right] \text { and } \mathrm{M}^{3+}+\mathrm{SB} \rightarrow\left[\mathrm{M}(\mathrm{SB})_{3}\right]
$$

Where, $\mathrm{M}^{2+}=\mathrm{Ni}$ (II), $\mathrm{Cu}$ (II), Co (II), Cd (II) and $\mathrm{Zn}$ (II) ions, $\mathrm{M}^{3+}=\mathrm{Cr}$ (III) ion, $\mathrm{SB}=$ Schiff base

A good yield of $60-70 \%$ was obtained and the purity of the complexes were confirmed by the elemental analysis.

\section{Results and Discussion}

All the complexes are stable at room temperature and are insoluble in common organic solvents but are soluble in DMSO, DMF and $\mathrm{CHCl}_{3}$.

\subsection{Elemental Analysis and Conductivity Measurement}

The elemental analysis and physical properties of the complexes are listed in Table 1 and Table 2. The analytical data were in good agreement with the proposed empirical formula of the complexes. The conductance values of the complexes revealed that those were non-electrolytes in nature. [19]. The obtained values imply that no anions present outside the coordination sphere in all the complexes [28].

Table 1. Elemental analysis of the ligand (Schiff base) and the complexes.

\begin{tabular}{|c|c|c|c|c|c|c|}
\hline \multirow{2}{*}{ Ligand and Complexes } & \multicolumn{2}{|l|}{$\%$ Carbon } & \multicolumn{2}{|c|}{ \% Hydrogen } & \multicolumn{2}{|l|}{$\%$ Nitrogen } \\
\hline & Calculated & Found & Calculated & Found & Calculated & Found \\
\hline $\mathrm{SB}\left(\mathrm{C}_{14} \mathrm{H}_{11} \mathrm{NO}_{3}\right)$ yellow powdered & 69.70 & 69.62 & 4.56 & 4.44 & 5.80 & 5.78 \\
\hline$\left[\mathrm{Ni}\left(\mathrm{C}_{14} \mathrm{H}_{11} \mathrm{NO}_{3}\right)_{2}\right]$ & 62.14 & 61.66 & 4.06 & 3.85 & 5.17 & 4.54 \\
\hline$\left[\mathrm{Cu}\left(\mathrm{C}_{14} \mathrm{H}_{11} \mathrm{NO}_{3}\right)_{2}\right]$ & 61.59 & 61.02 & 4.03 & 3.64 & 5.13 & 4.70 \\
\hline$\left[\mathrm{Co}\left(\mathrm{C}_{14} \mathrm{H}_{11} \mathrm{NO}_{3}\right)_{2}\right]$ & 62.11 & 61.32 & 4.06 & 3.88 & 5.17 & 4.92 \\
\hline$\left[\mathrm{Cd}\left(\mathrm{C}_{14} \mathrm{H}_{11} \mathrm{NO}_{3}\right)_{2}\right]$ & 56.52 & 55.96 & 3.70 & 3.12 & 4.71 & 4.20 \\
\hline$\left[\mathrm{Zn}\left(\mathrm{C}_{14} \mathrm{H}_{11} \mathrm{NO}_{3}\right)_{2}\right]$ & 61.38 & 60.45 & 4.01 & 3.74 & 5.11 & 4.88 \\
\hline
\end{tabular}

Where, $\mathrm{SB}=$ Schiff base.

Table 2. Physical properties of the ligand (Schiff base) and complexes.

\begin{tabular}{lllll}
\hline Complexes & Colour & Melting point or decomposition temp. $\left( \pm \mathbf{5}^{\circ} \mathbf{C}\right)$ & \% Yield & Molar conductance (ohm-2 cm2 mol-1) \\
\hline$\left[\mathrm{Ni}\left(\mathrm{C}_{14} \mathrm{H}_{11} \mathrm{NO}_{3}\right)_{2}\right]$ & Gray & 207 & 63 & 6.5 \\
{$\left[\mathrm{Cu}\left(\mathrm{C}_{14} \mathrm{H}_{11} \mathrm{NO}_{3}\right)_{2}\right]$} & Green & 213 & 68 & 10.6 \\
{$\left[\mathrm{Co}\left(\mathrm{C}_{14} \mathrm{H}_{11} \mathrm{NO}_{3}\right)_{2}\right]$} & Brown & 300 (above) & 66 & 6.7 \\
{$\left[\mathrm{Cd}\left(\mathrm{C}_{14} \mathrm{H}_{11} \mathrm{NO}_{3}\right)_{2}\right]$} & Orange & $270(\mathrm{~d})$ & 64 & 11.9 \\
{$\left[\mathrm{Zn}\left(\mathrm{C}_{14} \mathrm{H}_{11} \mathrm{NO}_{3}\right)_{2}\right]$} & Orange & 300 (above) & 59 & 22.9 \\
{$\left[\mathrm{Cr}\left(\mathrm{C}_{14} \mathrm{H}_{11} \mathrm{NO}_{3}\right)_{3}\right]$} & Brown & 300 (above) & 61 & 9.3 \\
$\mathrm{SB}:\left(\mathrm{C}_{14} \mathrm{H}_{11} \mathrm{NO}_{3}\right)$ & Yellow powdered & 232 & - & - \\
\hline
\end{tabular}

Where, $\mathrm{SB}=$ Schiff base

\subsection{Infrared (IR) Spectral Studies}

Infrared spectral data of the ligand and complexes were listed in Table 3. The spectral data of the ligands showed a strong absorption band at $(1550-1650) \mathrm{cm}^{-1}$ due to $v(\mathrm{C}=\mathrm{N})$ stretching [20-21] indicating the condensation have taken place between the $\mathrm{CHO}$ moiety of p- hydroxy benzaldehyde and $-\mathrm{NH}_{2}$ moiety of 4-aminobenzoic acid. Band at (3020$3165) \mathrm{cm}^{-1}$ is responsible due to aromatic $\mathrm{v}(\mathrm{C}-\mathrm{H})$ stretching.
A band at (3300-3500) $\mathrm{cm}^{-1}$ is liable due to $\mathrm{v}(\mathrm{N}-\mathrm{H})$ stretching of $v\left(\mathrm{NH}_{2}\right)$ modes. The Band at $(500-600) \mathrm{cm}^{-1}$ is accountable due to $v$ (M-N) stretching [22-23] which indicated the co-ordination through $\mathrm{N}$ atom to the metal. A band at $(1600-1800) \mathrm{cm}^{-1}$ due to $v(\mathrm{C}=\mathrm{O})$ stretching, band at (460-500) $\mathrm{cm}-1$ due to $v(\mathrm{M}-\mathrm{O})$ stretching [24], and a band at (3400-3600) $\mathrm{cm}^{-1}$ due to $v(\mathrm{O}-\mathrm{H})$ stretching. 
Md. Motahar Hossain et al: : Preparation, Physical Characterization and Antibacterial Activity of $\mathrm{Ni}$ (II), Cu (II), Co (II), Cd (II), Zn (II) and Cr (III) Schiff Base Complex Compounds.

Table 3. IR spectral data of the ligand and metal complexes.

\begin{tabular}{lllllll}
\hline Complexes & $\mathbf{v}(\mathbf{O}-\mathbf{H}) \mathbf{c m}-\mathbf{1}$ & $\mathbf{v}(\mathbf{C}=\mathbf{N}) \mathbf{c m}-\mathbf{1}$ & $\mathbf{v}(\mathbf{C}-\mathbf{H})$ of aromatic cm-1 & $\mathbf{v}(\mathbf{M}-\mathbf{O}) \mathbf{c m}-\mathbf{1}$ & $\mathbf{v}(\mathbf{M}-\mathbf{N}) \mathbf{c m}-\mathbf{1}$ & $\mathbf{v}(\mathbf{C}=\mathbf{O}) \mathbf{c m}-\mathbf{1}$ \\
\hline$\left[\mathrm{Ni}\left(\mathrm{C}_{14} \mathrm{H}_{11} \mathrm{NO}_{3}\right)_{2}\right]$ & 3412.24 & 1568.52 & 3050.10 & 495.93 & 534.39 & 1688.17 \\
{$\left[\mathrm{Cu}\left(\mathrm{C}_{14} \mathrm{H}_{11} \mathrm{NO}_{3}\right)_{2}\right]$} & 3404.20 & 1576.78 & 3070.87 & 426.54 & 527.05 & 1697.82 \\
{$\left[\mathrm{Co}\left(\mathrm{C}_{14} \mathrm{H}_{11} \mathrm{NO}_{3}\right)_{2}\right]$} & 3413.70 & 1568.76 & 3090.47 & 495.43 & 534.25 & 1683.02 \\
{$\left[\mathrm{Cd}\left(\mathrm{C}_{14} \mathrm{H}_{11} \mathrm{NO}_{3}\right)_{2}\right]$} & 3401.35 & 1569.91 & 3070.10 & 495.56 & 534.53 & 1686.03 \\
{$\left[\mathrm{Zn}\left(\mathrm{C}_{14} \mathrm{H}_{11} \mathrm{NO}_{3}\right)_{2}\right]$} & 3402.10 & 1570.50 & 3098.10 & 495.41 & 534.28 & 1688.62 \\
{$\left[\mathrm{Cr}\left(\mathrm{C}_{14} \mathrm{H}_{11} \mathrm{NO}_{3}\right)_{3}\right]$} & 3449.89 & 1575.17 & 3071 & 484.25 & 527.07 & 1693.04 \\
\hline
\end{tabular}

\subsection{Magnetic Moment and Electronic Spectra}

The observed magnetic moment values of the complexes at ambient temperature are given in Table-4. The magnetic moment value of $\mathrm{Ni}$ (II) complex is diamagnetic which indicating the absence of unpaired electron. It appears from the magnetic moment data that complex is a low spin Square planar [25] complex. The observed magnetic moment value of $\mathrm{Cu}$ (II) complex was found to be $2.21 \mathrm{~B}$. M. corresponding to one unpaired electron. It appears from the magnetic moment data that complex is a high spin tetrahedral complex. The observed magnetic moment value of Co (II) complex was observed $1.96 \mathrm{~B}$. M. corresponding to one unpaired electron. It appears from the magnetic moment data that complex is also a high spin Square planar complex. The observed magnetic moment value of Cd (II) complex is diamagnetic indicating the absence of unpaired electron. It appears from the magnetic moment data that complex is a low spin tetrahedral complex. The observed magnetic moment value of $\mathrm{Zn}$ (II) complex is diamagnetic indicating the absence of unpaired electron. It appears from the magnetic moment data that complex is a low spin tetrahedral complex. The observed magnetic moment value of $\mathrm{Cr}$ (III) complex is 3.89 B. M. corresponding to three unpaired electrons. It appears from the magnetic moment data that complex is a high spin octahedral [21] complex.

The electronic spectral data of the complexes are shown in Table 5. The electronic spectrum for the complexes are $298 \mathrm{~nm}$, $297 \mathrm{~nm}, 336 \mathrm{~nm} 300 \mathrm{~nm}$ and $302 \mathrm{~nm}$. These electronic spectra show bands in the region $200-420 \mathrm{~nm}$ due to charge transfer only [25]. The UV-visible spectrum of the complex of $\mathrm{Cr}$ (III) show an absorption band at $430 \mathrm{~nm}$ which is assigned the complex in an octahedral geometry [26].

Table 4. Magnetic moment data of the complexes.

\begin{tabular}{llllll}
\hline Complexes & $\begin{array}{l}\text { Length of the sample, } \\
\text { 'l' in cm }\end{array}$ & $\begin{array}{l}\text { weight of the sample } \\
\text { 'm' in g }\end{array}$ & $\begin{array}{l}\text { Susceptibility of the } \\
\text { cmpty tube, Ro }\end{array}$ & $\begin{array}{l}\text { Susceptibility of the } \\
\text { sample with tube. } \mathbf{R}\end{array}$ & $\begin{array}{l}\text { Mass Susceptibility } \\
\boldsymbol{\chi} \mathbf{g} \times \mathbf{1 0}^{-6} \mathbf{C . G . S ~ u n i t}\end{array}$ \\
\hline$\left[\mathrm{Ni}\left(\mathrm{C}_{14} \mathrm{H}_{11} \mathrm{NO}_{3}\right)_{2}\right]$ & 2.3 & 0.0602 & -61 & -68 & -0.557 \\
{$\left[\mathrm{Cu}\left(\mathrm{C}_{14} \mathrm{H}_{11} \mathrm{NO}_{3}\right)_{2}\right]$} & 2.1 & 0.0457 & -67 & -33 & 3.259 \\
{$\left[\mathrm{Co}\left(\mathrm{C}_{14} \mathrm{H}_{11} \mathrm{NO}_{3}\right)_{2}\right]$} & 2.8 & 0.0593 & -68 & -43 & 2.46 \\
{$\left[\mathrm{Cd}\left(\mathrm{C}_{14} \mathrm{H}_{11} \mathrm{NO}_{3}\right)_{2}\right]$} & 2.5 & 0.0784 & -41 & -60 & -1.2638 \\
{$\left[\mathrm{Zn}\left(\mathrm{C}_{14} \mathrm{H}_{11} \mathrm{NO}_{3}\right)_{2}\right]$} & 2.5 & -0599 & -68 & -72 & -0.870 \\
{$\left[\mathrm{Cr}\left(\mathrm{C}_{14} \mathrm{H}_{11} \mathrm{NO}_{3}\right)_{3}\right]$} & 2.1 & .0212 & -66 & -30 & 7.79 \\
\hline
\end{tabular}

Table 4. Continued.

\begin{tabular}{|c|c|c|c|c|c|}
\hline Complexes & $\begin{array}{l}\text { Molecular weight of the } \\
\text { sample, M }\end{array}$ & $\begin{array}{l}\text { Molecular susceptibility } \\
\chi \mathrm{m} \times 10^{-6} \text { C.G.S. unit }\end{array}$ & $\begin{array}{l}\text { Dimagnetic correction } \\
\chi \mathrm{L} \times 10^{-6} \text { C.G.S. unit }\end{array}$ & $\begin{array}{l}\chi \text { mcorr } \times 10^{-6} \\
\text { C.G.S. unit }\end{array}$ & $\mu$ eff in B. M. \\
\hline$\left[\mathrm{Ni}\left(\mathrm{C}_{14} \mathrm{H}_{11} \mathrm{NO}_{3}\right)_{2}\right]$ & 540.69 & -301.16 & -270.84 & -30.32 & dia \\
\hline$\left[\mathrm{Cu}\left(\mathrm{C}_{14} \mathrm{H}_{11} \mathrm{NO}_{3}\right)_{2}\right]$ & 545.54 & 1777.91 & -270.84 & 2048.75 & 2.21 \\
\hline$\left[\mathrm{Co}\left(\mathrm{C}_{14} \mathrm{H}_{11} \mathrm{NO}_{3}\right)_{2}\right]$ & 540.93 & 1330.68 & -270.84 & 1601.52 & 1.96 \\
\hline$\left[\mathrm{Cd}\left(\mathrm{C}_{14} \mathrm{H}_{11} \mathrm{NO}_{3}\right)_{2}\right]$ & 594.41 & -751.21 & -272.84 & -487.37 & dia \\
\hline$\left[\mathrm{Zn}\left(\mathrm{C}_{14} \mathrm{H}_{11} \mathrm{NO}_{3}\right)_{2}\right]$ & 547.39 & -476.23 & -272.84 & -203.39 & dia \\
\hline$\left[\mathrm{Cr}\left(\mathrm{C}_{14} \mathrm{H}_{11} \mathrm{NO}_{3}\right)_{3}\right]$ & 774.99 & 6037.17 & -273.84 & 6301.01 & 3.89 \\
\hline
\end{tabular}

Table 5. Electronic spectral data of complexes.

\begin{tabular}{ll}
\hline Complexes & $\boldsymbol{\lambda}_{\max }(\mathbf{n m})$ \\
\hline$\left[\mathrm{Ni}\left(\mathrm{C}_{14} \mathrm{H}_{11} \mathrm{NO}_{3}\right)_{2}\right]$ & 298 \\
{$\left[\mathrm{Cu}\left(\mathrm{C}_{14} \mathrm{H}_{11} \mathrm{NO}_{3}\right)_{2}\right]$} & 297 \\
{$\left[\mathrm{Co}\left(\mathrm{C}_{14} \mathrm{H}_{11} \mathrm{NO}_{3}\right)_{2}\right]$} & 336 \\
{$\left[\mathrm{Cd}\left(\mathrm{C}_{14} \mathrm{H}_{11} \mathrm{NO}_{3}\right)_{2}\right]$} & 300 \\
{$\left[\mathrm{Zn}\left(\mathrm{C}_{14} \mathrm{H}_{11} \mathrm{NO}_{3}\right)_{2}\right]$} & 302 \\
{$\left[\mathrm{Cr}\left(\mathrm{C}_{14} \mathrm{H}_{11} \mathrm{NO}_{3}\right)_{3}\right]$} & 304,430 \\
\hline
\end{tabular}




\section{Structure of the Complexes}

From the above discussion (elemental analysis, conductivity measurement, magnetic moment and electronic spectra, IR spectra) and the literature review, it can be concluded that the possible structures of the complexes are given below:

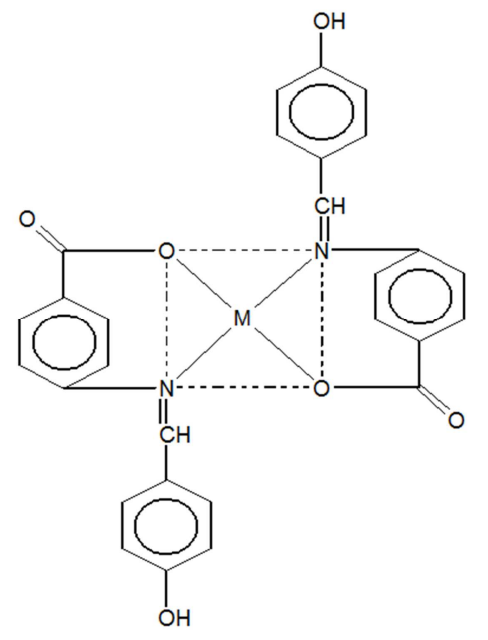

Figure 3. Probable structure of the complexes, Here, $M=N i$ (II) and Co(II).

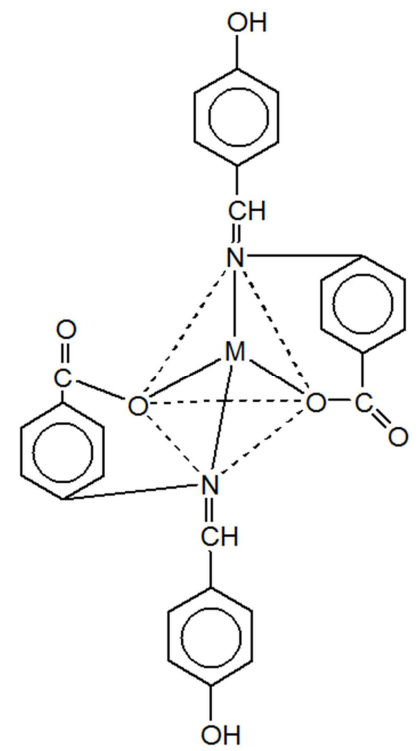

Figure 4. Probable structure of the complexes, Here, $\mathrm{M}=\mathrm{Cu}$ (II), $\mathrm{Cd}$ (II) and Zn (II).

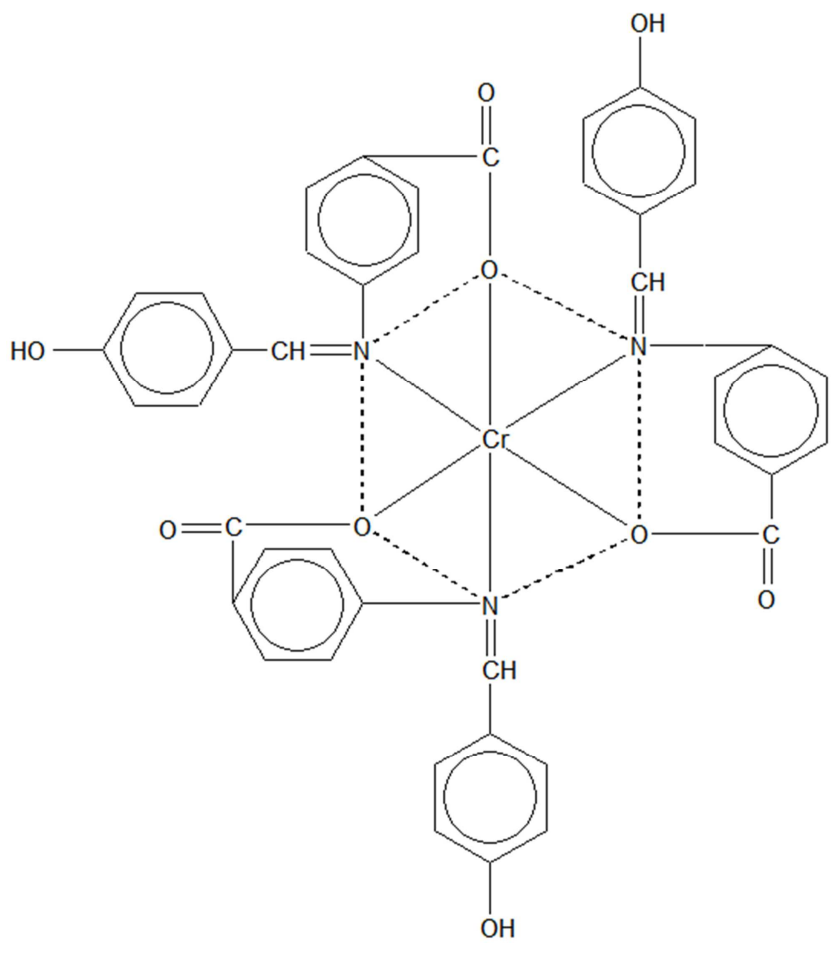

Figure 5. Probable structure of Cr (III) complex.

\section{Antibacterial Activity of the Metal Complexes}

Antimicrobial screening activities of the test samples are expressed by measuring the zone of inhibition observed around the area as shown in Table 6 . The results revealed that the complexes are more microbial toxic than the free metal ions or ligands. All the complexes of metals under investigations more as well as less activities against the four pathogenic (two gram-positive and two gram-negative) bacteria tested. The results also revealed that among all the tested samples, these metal complexes showed strong activity against both the Gram positive and Gram-negative bacteria.

Table 6. Antibacterial screening activity of the complexes against gram-positive and gram-negative bacteria.

\begin{tabular}{|c|c|c|c|c|}
\hline \multirow{3}{*}{ Compounds } & \multicolumn{4}{|c|}{ Zone of inhibition, diameter in $\mathrm{mm}$} \\
\hline & \multicolumn{2}{|c|}{ Gram-Negative } & \multicolumn{2}{|l|}{ Gram Positive } \\
\hline & Escherichia coli & Shigella dysenteriae & Bacillus cereus & Streptococcus agalactiae \\
\hline$\left[\mathrm{Ni}\left(\mathrm{C}_{14} \mathrm{H}_{11} \mathrm{NO}_{3}\right)_{2}\right]$ & 9 & 15 & 13 & 12 \\
\hline$\left[\mathrm{Cu}\left(\mathrm{C}_{14} \mathrm{H}_{11} \mathrm{NO}_{3}\right)_{2}\right]$ & 14 & 11 & 12 & 13 \\
\hline$\left[\mathrm{Co}\left(\mathrm{C}_{14} \mathrm{H}_{11} \mathrm{NO}_{3}\right)_{2}\right]$ & 6 & 11 & 5 & 9 \\
\hline$\left[\mathrm{Cd}\left(\mathrm{C}_{14} \mathrm{H}_{11} \mathrm{NO}_{3}\right)_{2}\right]$ & 9 & - & 6 & 7 \\
\hline$\left[\mathrm{Zn}\left(\mathrm{C}_{14} \mathrm{H}_{11} \mathrm{NO}_{3}\right)_{2}\right]$ & 11 & 16 & 7 & 12 \\
\hline$\left[\mathrm{Cr}\left(\mathrm{C}_{14} \mathrm{H}_{11} \mathrm{NO}_{3}\right)_{3}\right]$ & 10 & 5 & 9 & 8 \\
\hline
\end{tabular}

\section{Conclusion}

Magnetic susceptibility measurement indicated that the $\mathrm{Ni}$
(II), Cd (II) and Zn (II) complexes with Schiff base are the diamagnetic and the rest of the complexes are paramagnetic in nature. The IR spectral data showed that all the metals are coordinated through $\mathrm{N}(\mathrm{N}$ of $-\mathrm{N}=\mathrm{CH}-$ and $\mathrm{O}$ of - 
COO group of Schiff base) and O atom of the Schiff base the ligand coordinate with the metal. The electronic spectral data were in conformity with the $\mathrm{Ni}$ (II) and Co (II) are square planar structure of the complexes, $\mathrm{Cu}$ (II), $\mathrm{Cd}$ (II) and $\mathrm{Zn}$ (II) tetrahedral structure of complexes and octahedral structure of complex of $\mathrm{Cr}$ (III). Based on these above results and facts, the structures of complexes have been proposed as shown in Figure 3, 4 and 5. The $\mathrm{Cu}$ (II) complex shows the highest (potent) antimicrobial activity against gram-positive and gram-negative pathogenic bacteria according to standard kanamycin and ampicillin., Ni (II) and Zn (II) has potent antimicrobial activity against all the gram-positive and gramnegative pathogenic bacteria and the rest Co (II), Cd (II) and $\mathrm{Cr}$ (II) complexes with Schiff base exhibit moderate to less antimicrobial activity compared to examined complexes.

\section{References}

[1] Alim, A., Zahan, M. K. E., Haque, M. M. and Tarafder, M. T. H., Synthesis and Characterization of Some Metal Complexes of $\mathrm{Cu}$ (II), Ni (II), Zn (II), Cd (II), Sn (II), Co (II), Sb (III) AND Fe (III) Containing Bidentate Schiff Base of Smdtc, Science Journal of Chemistry, 2015; 3 (3): 35-39.

[2] Banu, L. A., Islam, M. S., Al-Bari, M. A. A. and Zahan, M. K. E., Synthesis and Characterization with Antibacterial, Antifungal, Cytotoxicity Studies on the Co (II), Ni (II) and Cu (II) complexes of Tridentate ONO Coordinating Schiff Bases and Heterocyclic Amines, International Journal of Recent Advances in Multidisciplinary Research, 2015; 02 (01): 145148 .

[3] Shampa, J. A., Islam, M. R., Hossain, M. S., Rahman, G. T., Zakaria, C. M. and Zahan, M. K. E., Physiochemical and Antibacterial Activity Investigation on Noble Schiff Base $\mathrm{Cu}$ (II) Complex, American Journal of Heterocyclic Chemistry, 2017; 3 (4): 37-41.

[4] Hossain, M. S., Islam, M. A., Zakaria, C. M., Haque, M. M., Mannan, M. A. and Md. Zahan, M. K. E., Synthesis, Spectral and Thermal Characterization with Antimicrobial Studies on Mn (II), Fe (II), Co (II) and Sn (II) Complexes of Tridentate N, O Coordinating Novel Schiff Base Ligand, J. Chem. Bio. Phy. Sci. Sec. A, 2017; 7 (1): 041-052.

[5] Hossain, M. S., Sarker, S., Shaheed, A. S. M. E., Hossain, M. M., Bari, A. A., Karim, M. R., Zakaria, C. M., and Zahan, M. K. E., Thermal and Spectral Characterization of Cr (III), Co (II) and Cd (II) Metal Complexes Containing Bis Imine Novel Schiff Base Ligand Towards Potential Biological Application, Chemical and Biomolecular Engineering, 2017; 2 (1): 41-50.

[6] Patel, K. M., Patel, K. N., Patel N. H. and Patel M. N., Synthesis, characterization, and antimicrobial activities of some transition metal complexes with a tridentate dibasic Schiff base and bidentate 2, 2'-bipyridylamine. Synth. React. Inorg. Met-Org. Chem., 2001; 239.

[7] Temel H., Cakir Ü., Ugras H. I. and Sekerci M., The Synthesis, Characterization and Conductance Studies of New Co (III), Cu (II), Ni (II) and Zn (II) Complexes with Schiff Base Derived from 1, 2-bis- (o-aminophenoxy) Ethane and Salicylaldehyde. Journal of Coord. Chem., 2003; 56: 943-951.

[8] Liang Y., SU, B., Zhao I. and Sun W., The Synthesis of New Asymmetric Double Schiff Bases Containing a New o-
Amino Benzoic Acid Derivative. Synthesis Communications, 2004; 34: 3235-3242.

[9] Venkataraman, N. S., Kuppuraj, G. and Rajajopal, S., Metalsalen complexes as efficient catalysts for the oxygenation of heteroatom containing organic compounds-synthetic and mechanistic aspects. Coord. Chem. Rev., 2005; 249: 12491268 .

[10] Mohamed, G. G., Omar, M. M. and Hindy, A. M., Metal complexes of Schiff bases: preparation, characterization and biological activity. J. Turk. Chem., 2006; 30: 361-382.

[11] Diego, M., Veronica, D., Claudia, P., Jean, P. T. and Sandra, S., Synthesis, characterization and antioxidant activity of water soluble Mn (III) complexes of sulphonato-substituted Schiff base ligands. Journal of inorganic Biochemistry, 2010; 104: 496-502.

[12] Khalil, M., Ismail, E., Mohamed, G., Zayed E. and Badr, A., Synthesis and characterization of a novel schiff base metal complexes and their application in determination of iron in different types of natural water. Open J. Inorg. Chem., 2012; 2: $13-21$.

[13] Abu-El-Wafa, S. M., El-Wakiel, N. A., Issa R. M., and Mansour, R. A., Formation of novel mono-and multi-nuclear complexes of Mn (II), Co (II) and Cu (II) with bisazo-dianils containing the pyrimidine moiety: Thermal, magnetic and spectral studies. J. Coord. Chem., 2005; 58: 683-694.

[14] Etaiw S. H., Abd El-Aziz D. M., Abd El-Zaher E. H. and Ali E. A., Synthesis, spectral, antimicrobial and antitumor assessment of Schiff base derived from 2-aminobenzothiazole and its transition metal complexes, Spectrochim. Acta A., 2011; 79: 1331-1337.

[15] Ueda J. I., Takai N. and Shiazue Y., Reactive Oxygen Species Generated from the Reaction of Copper (II) Complexes with Biological Reductants Cause DNA Strand Scission. Arch. Biochem. Biophys., 1998; 357: 231-239.

[16] Radhakrishnan P. K., Complexes of lanthanide perchlorates with 4-N- (2'-hydroxy-1'-naphthylidene) aminoantipyrine, Polyhedron. 1986; 5: 995-998.

[17] Maurya R. C., Mishra D. D., Pandey M., Shukla P. and Rathour R., Synthesis and spectral studies of octacoordinated dioxouranium (VI) complexes with some Schiff bases derived from 4-Acetyl-2, 3-Dimethyl-1- (4-Methylphenyl)-3Pyrazoline-5-One and aromatic amines. Synth. React. Inorg. Met. Org. Chem., 1993; 23: 161-174.

[18] Kudrat-E- Z. M., Islam, M. S. and Bashar M. A., Synthesis, Characterization and antimicrobial activity of Some Metal Complexes of $\mathrm{Mn}$ (II), $\mathrm{Fe}$ (III) $\mathrm{Co}$ (II), $\mathrm{Ni}$ (II), $\mathrm{Cu}$ (II) and $\mathrm{Sb}$ (III) Containing Bidentate Schiff base of SMDTC. Russian Journal of general chemistry, 2015; 85 (3): 667-672.

[19] Geary, W. J., The use of conductivity measurements in organic solvents for the characterization of coordination compounds, Coord. Chem. Rev., 1971; 7: 81-122.

[20] Shamsuddin, A. A. K., Benui:, K. Dey., Zainul, S. A., and datta:, M., J. Bang. Chem. Soc., 1999; 12 (1): 25.

[21] Md. Saddam Hossain, C. M. Zakaria, M. M. Haque, and Md. Kudrat-E- Zahan, (2016) Spectral and Thermal Characterization with Antimicrobial Activity on Cr (III) and Sn (II) Complexes containing N, O Donor Novel Schiff Base Ligand. International Journal of Chemical Studie, 2016; 4 (6): 08-11. 
[22] Hutchinson, B., Takemoto J. and Nakamoto, K., Metal isotope effect on metal-ligand vibration. II. Tris complexes of 2, 2' bipyridine and 1, 10-phenanthroline, J. Am. Chem. Soc., 1970, 92: 3335 .

[23] Saito, Y., Takemoto, J., Hutchinson B. and Nakamoto, K., Infrared studies of coordination compounds containing lowoxidation state metals. I. Tris $\left(2,-2^{\prime}\right.$-bipyridine $)$ and tris $(1,10$ phenanthroline) complexes, Inorg. Chem., 1972, 11: 2003.

[24] Nakamoto, K., Infrared spectra of inorganic and coordination compounds. John Wiley and Sons. New York, 1963, 112: 227.

[25] Lever, A. B. P., Inorganic Electronic Spectroscopy, $2^{\text {nd }}$ Edn. Elsevier (1984).

[26] Md. Saddam Hossain, Shudeepta Sarker, A. S. M. Elias
Shaheed, Md. Mamun Hossain, Abdul Alim-Al-Bari, Md. Rabiul Karim, C. M. Zakaria, Md. Kudrat-E-Zahan. (2017) Thermal and Spectral Characterization of Cr (III), Co (II) and Cd (II) Metal Complexes Containing Bis-Imine Novel Schiff Base Ligand Towards Potential Biological Application. Chemical and Biomolecular Engineering., 2017, 2 (1): 41-50.

[27] El-ajaily, M. M., Maihub, A. A., Hudere S. S. \& Ben Saber S. M. (2006). Nickel II Chelate of Schiff base derived from 4dimethyl-amino-benzaaldehyde with Systeine. Asian Journal of Chemistry Society, 2006; 18 (4): 2427- 2430.

[28] F. M. Morad, F. M., M. M. EL. ajaily, M. M. EL. and Gweirif, S. B., Preparation, Physical Characterization and Antibacterial Activity of Ni (II) Schiff Base Complex, Journal of Science and Its Applications, 2007; 1 (1): 72-78. 